Cahiers $d u$ MONDE RUSSE

\section{Cahiers du monde russe}

Russie - Empire russe - Union soviétique et États indépendants

$53 / 4 \mid 2012$

Varia

\title{
Catherine Evtuhov, Portrait of a Russian Province
}

\author{
Olga E. Glagoleva
}

URL: http://journals.openedition.org/monderusse/7852

DOI: 10.4000/monderusse.7852

ISSN: $1777-5388$

Publisher

Éditions de l'EHESS

\section{Printed version}

Date of publication: 15 December 2012

ISSN: $1252-6576$

Electronic reference

Olga E. Glagoleva, « Catherine Evtuhov, Portrait of a Russian Province», Cahiers du monde russe [Online], 53/4 | 2012, Online since 08 October 2013, Connection on 22 September 2020. URL : http:// journals.openedition.org/monderusse/7852 ; DOI : https://doi.org/10.4000/monderusse.7852

This text was automatically generated on 22 September 2020

(c) École des hautes études en sciences sociales 


\title{
Catherine Evtuhov, Portrait of a Russian Province
}

\author{
Olga E. Glagoleva
}

\section{REFERENCES}

Catherine Evtuhov, Portrait of a Russian Province. Economy, Society, and

Civilization in Nineteenth-Century Nizhnii Novgorod. Pittsburgh : University of Pittsburgh Press, 2011, 320 p. [Pitt series in Russian and East European studies]

1 Until only recently, focus on local history was considered a limitation of a study. In Russian and Soviet traditional historiography such a study would have been named kraevedcheskaia rabota, meaning a non-academic, even unprofessional one. With the advancement of the micro history and local history approaches at the turn of the $21^{\text {st }}$ century, historical research has dramatically changed its focus and goals. The study under review is an excellent example of micro-history research with macro-history conclusions. Catherine Evtuhov demonstrates her fascination with the local - what she names "economy, society and civilization in the nineteenth-century Nizhnii Novgorod." Rich in details, the book under review leaves no issue of local history and economy of the Nizhnii Novgorod province unturned.

2 Evtuhov believes that a province's portrait can only be drawn through portraits of people who lived there and dedicated their lives to the province. To be more specific, the author says that "Russian provincialism was a creation of an intelligentsia" and emphasizes her interest "not merely in the 'provincial activist' (provincial'nyi deiatel'), of whom there were hundreds or even thousands throughout Russia, but in particular persons whose goal was to depict, describe, conceptualize, present, and promote the province" (p. 15). Four such "purveyors of the province" - ethnographer and editor of a local newspaper P.I. Mel'nikov (better known as the novelist Andrei Pecherskii), purveyor A.S. Gatsiskii, photographer A.O. Karelin, and environmental scientist V.V. Dokuchaev - became the protagonists of the book, and at the same time its 
creators, as Evtuhov, admitting that her book "could not have been written without the purveyors" (p. 15), heavily bases her research on their works. She opens the section on their biographies (in chapter 1, "Imagining the Russian Provinces") with their portraits, a nice personalizing touch on the history of the region.

The main achievement of the book is that Evtuhov challenges the stereotypes. She looks at familiar matters from a different perspective - a local one in particular. In the geographical survey of the region (chapter 2, "Soil, Forest, River: The Ecology of Provincial Life"), Evtuhov depicts the Volga river as an ever changing substance, with its own character, mysteriously disappearing islands, flowing paths and varying soils, which determined not only the ecology of the province but the economy and local people's lifestyles. Thus, the common image of the river that served as a great trade way between Europe and Asia, provided people with rich soils and abundant fish resources, is replaced, from the local perspective, by a picture of the Volga bringing about not only those advantages but also a constant danger of mudslides (which caused the entire Pecherskii Monastery to slip into the river in 1596) or changing riverbeds (which caused troubles for navigation). In the topographical description of the gubernia (chapters 3, "Urban Topography" and 6, " Social Space"), Evtuhov underlines the blurred boundaries between urban and rural life. Thus, in the "village" of Bol'shoe Murashkino in the Chernozem soil region, all of the inhabitants ( 890 households!) were engaged not in agricultural activities of any sort but in leather production and sheepskin manufacturing; in the town of Makar'ev, a district center, no administrative organs were located, except for the municipal board, as the administration had moved to the nearest town of Lyskovo. The latter became "a shadow capital" while the official district center remained, in the view of local statisticians, "quite possibly the most pathetic of district towns in all of Russia, more like a village than a city" (p. 55). The example of Makar'ev embodies, for Evtuhov, "a failed Petersburgian ideal" of a district town as "the pure administrative center." Yet the presence of "organic," "nonadministrative" towns like Lyskovo undermines a familiar image of the rural uniformity of provincial Russia. On the other hand, Evtuhov finds no link between the development of industry and urban life in the Nizhnii Novgorod province - the wellknown steel and iron works in Pavlovo and even the shipyards in Sormovo, although functioning as large factories, were not concentrated in one place or in a group of factory buildings but scattered over an extended territory, none of them operating in an urban setting. While looking into the peculiarities of local urban or country life, the author reduces the scope of their description to a street, to a household.

4 The economy (chapters 4, "Rhythms: The Local Economy" and 5, "An Artisanal Case Study: The Southeast") is, too, viewed not as a national or regional phenomenon but as a village or even family business. Meticulous depiction of production processes reveals unexpected aspects of well-known things: thus, the traditional local wooden-spoon home craft, which looks rather primitive, natural and ecologically clean, turns out to be loaded with hard labour and conducive to forest annihilation, as only the wood of a tree near its roots is used for making spoons. Production of simple things for everyday life is shown as a rather sophisticated process necessitating high specialization and involvement of all family members. Quite often was it harmful to people's health, children's and women's in particular, although final sales usually brought very low profits to the producers. The trade, unlike in other Russian provinces, was largely carried out by Old Believers - rich and educated merchants who took control over local artisanal production in the Nizhnii Novgorod province, established their own financial 
and commercial networks, and became very influential in local economy and social environment. Their influence in the religious sphere (chapter 9, "Church and Religion") was felt in the region as "a constant 'infection' (the official term) of Orthodoxy with old Belief." However, the dialogue between the two "ensured a continuing re-examination of fundamental assumptions of faith" which made the religious sphere particularly "amenable to local initiative and participation" (p. 204). The juxtaposition of central control and local initiative is tested in two other chapters, "Managing the Province: Local Administration" (\#7) and "The Cadastral Map in the Service of the Zemstvo" (\#8) which deal with the government reforms of the 1860s and the activities of local zemstvos.

5 The book is replete with statistics - numbers, tables and diagrams of various kinds fill the pages, in particular in chapter 6, "Social Space: Numbers, Images, Biographies," as Evtuhov is fascinated by the data collected by local purveyors. Excellent sources, their published surveys with data on "every imaginable topic: meteorology, ethnography, topography, criminality, education, social insurance, rural medicine, religion, local history" (p. 4) were supplemented by textual descriptions of many aspects of local life, as well as biographies and images (photographs) of local people from all walks of life. The abundance and richness of published sources on provincial life in Russia in the second half of the $19^{\text {th }}$ century can make envious the historian of any of the earlier periods of history. For Evtuhov, the local purveyors' published works are "an archive unto themselves, distinguished from a 'real' archive primarily by their greater legibility" (p. 4-5). As distinct from other social historians who, "in their effort to apprehend the complexities of post-reform 'social-flux' compounded by statesponsored industrialization, have, perhaps naturally, evinced a strong urge to have immediate recourse 'to archives'," Evtuhov believes that the "most obvious" sources for the nineteenth century Russian history are the local intelligentsia's published works, which better depict the peculiarities of local life than official documents preserved in archives "with their administrative bias" (p. 82, 251, n. 4). That allows Evtuhov to look only occasionally at documents in local and central archives, as she makes references to only ten archival fonds - document collections in archives of Nizhnii Novgorod, Moscow (one fond) and St. Petersburg (two fonds) in the whole book and to not more than a dozen of actual dela in them. For a historian working in the field of Russian local history of the $18^{\text {th }}$ and $19^{\text {th }}$ centuries like myself, this contraposition of the official archival sources and the published materials of the kraevedy looks a bit superficial. For sure, work with published sources spares a historian a great deal of time, in comparison with the time-consuming archival work often complicated by illegible scripts of handwritten documents. Nevertheless, the "administrative bias" of the documents collected by the regional and central administration, true as it may be, could serve as a good counterbalance to the enthusiastic bias of pioneers of local history, often revealed in their passionate writings. Apart from this source-related problem, within the boundaries of the chosen sources, Evtuhov analyzes them skilfully and thoroughly and, often, in innovative ways.

In her "Preface" the author performs a little trick - she allows "the impatient reader" not to follow the book design which proceeds "from the details of the natural environment through social and economic activities and structures to culture and ideas" but to start instead with chapter 7, "Managing the Province," or chapter 11, "The Idea of Province," and then choose which of the earlier chapters seems attractive (p. ii). The permission looked tempting, so, as a cultural historian, soon after reading 
the beginning of the book, I turned to chapter 10 with the promising name of "Provincial Cultural Nests". My imagination immediately drew a familiar nostalgic picture of decaying provincial noble estates, with young girls sitting idle and dreaming of going "to Moscow, to Moscow," while the sounds of gardens being cut leaves them nothing to wish to stay for. To my surprise, I found no such picture in the book. Instead, a well nuanced depiction of a rich and fast-developing provincial cultural milieu, mostly urban, was offered: a system of schools and libraries, local press and theatre, music and science, and a group of local people of various rank organizing an archive and museum. True, similar processes took place, in the post-emancipation Russia, in many big cities all over the country. Yet, the cultural milieu of the Nizhnii Novgorod province had its own face - while, to pick one example, museums in most of the regional centers resulted from a growing interest to the past on the part of enthusiasts-kraevedy, the Nizhnii Novgorod museum emerged as a natural history museum soon to become an independent scientific institution that conducted its own scientific research and established broad scientific relations, even with the international academic communities.

7 The most interesting chapter for me was the last, "The Idea of Province." Historians have lately tried to pin down the ambiguous terms of 'province,' 'provincialism' and ' provintsial'nost' in the Russian context, going beyond the traditional dichotomies of 'center - province/developed - undeveloped' and alike. ${ }^{1}$ Evtuhov takes this task even further: she tries to sketch an "idea of province" starting with provincials' own definition of the province. '"Province' meant, first of all, what our purveyors themselves thought it meant," writes Evtuhov and elaborates on the idea in three subchapters, "Province as Biography: Gatsiskii," "Province as Local Economy," and "Province and History." Aleksandr Gatsiskii, a local purveyor to whose biography and writings Evtuhov turns time and again in her book, stands for her as an embodiment of those people "whose lives began and ended on the local level (whether or not they were born in the province to which they dedicated their lives)" (p. 234). Gatsiskii believed that "provintsiia really exists" and the local administration, zemstvo, schools, courts and other local institutions had proved its existence (p. 234-235). Evtuhov adds to this notion some philosophical conceptualization. Borrowing Sergei Bulgakov's idea of economy as "the working, interactive relation of man and nature," Evtuhov formulates "an essential principle of provincial life, namely, the intrinsic power of khoziaistvo or economic life: on the local level, we can understand economy as politics" (p. 235). Evtuhov sees the local economy as a sphere where central government and local administration could reach consensus: when acting within the boundaries set out by the central power, local institutions could establish a considerable autonomy and independence. No less important in the process of political and social self-definition was to the provincials, as Evtuhov points out, the emergence of a local historical consciousness. "A collective discovery of a local past" (p. 242) helped them develop local pride and the notion of their significant place in the country and her history. This concept of province as "a world in motion", with its diversity and complexity, is an important step forward in our understanding of the relations between the center and the periphery in Russia.

8 Evtuhov entirely shares her purveyors' passion for the province and their goal to present and promote it, herself trying to promote her study of Nizhnii Novgorod as "a 'model' or example for the investigation of Russian regions", in a bigger goal to obtain "a picture of Russia far different from the one we are accustomed to seeing through a 
centralized, horizontally oriented historiography" (p. 250). Her ambitious study bears impressive results as the book makes us rethink the image of province and discover new dimensions of Russian history.

\section{NOTES}

1. See the discussion of the topic in my article: O.E. Glagoleva, "Dvorianstvo, vlast' i obshchestvo v provintsial'noi Rossii XVIII v.: Podkhody i metody izucheniia," in Olga Glagoleva and Ingrid Schierle, eds., Dvorianstvo, vlast' $i$ obshchestvo v provintsial'noi Rossii XVIII v. M., 2012, p. 9-48, esp. p. 16-23. 